intended to withstand heat have plumbago mixed in the inner surface of the vessels. There are many fanciful designs of this ware, some very large jars, pots of all shapes, bowls, cups, pitchers, etc.

Ridgewood, N. J. HenRy Hales.

\section{The Sense of Boundary in Dogs.}

I HAVE followed with mush interest the discussion in Science caused by the recent communication of my friend, Dr. Hall, entitled "Is there a Sense of Direction?"

Dr. Hall's query recalls to $\mathrm{m} 5$ mind a striking example of animal intelligence which I witnessed in a dog, and of which I sent a brief notice at the time to the London Spectator.

Some eight years ago I was staying with friends who had a fullblooded Irish deer-hound. On the adjoining estate lived a pointer. Our dog was scarcely more than a year old, while our neighbor's dog was quite well along in life. The dogs had never been friendly; indeed, from the first, the pointer manifested a decided aversion to the young deer-hound. Whenever the old dog caught his youthful neighbor trespassing be would immediately drive him back over the boundary between the estates. Both dogs, even when going at full speed, would invariably stop the moment our dog had crossed the line. The two estates are virtually continuous, there being neither hedge nor fence separating them. The dividing line runs between two stone posts about a foot in height and some two hundred feet apart. These posts, of the existence of which I was quite unaware, until the singular behavior of the dogs called my attention to them, are in the summer time usually hidden by the grass, and in winter are often buried under the snow. I mention them, not because I think it at all probable they served as guides to the dogs in determining the boundary line, but merely because they enabled us to observe more accurately the phenomenon in question. .

This exhibition of canine intelligence was first observed by my neighbors, who kindly pointed it out to me. It was repeat $\epsilon$ d almost daily for several months, and was a constant source of amusement and wonder to those who witnessed it. The question arises, How did the pointer know where the line ran, and how did his canine neighbor know when he was safely across it? The only answer which occurs to the writer is, that dogs (some dogs, certainly) possess a very acute sense of boundary.

Whether this sense is shared by other animals I am unable to say, though, on this point, it is possible that some of your readers may be able to throw light. The question is certainly an interesting one from its bearing on the general question of animal intelligence.

Berlin, Germany, Feb. 28.

F. TUCKERMAN.

\section{The Results of Search for Paleolithic Implements in the Ohio Valley.}

THOSE engaged in the recent discussion of Glacial Man have had little to say of the Ohio Valley. Without laying any claim whatever to geologic skill. I will submit some extracts from my private journal. These are submitted from the standpoint of a "field searcher" who knows nearly all the village sites and primitive remains of southern Obio.

"May, 1891. Found in ash-pits near the Little Miami River, at Fort Ancient (Warren County), several objects of the character of those in the United States National Museum labelled from New Jersey and District of Columbia, commonly called paleoliths. These are in various styles - broken and whole, rude and well formed, large and small. Pottery fragments, bones, and flint chips side by side with the rough forms.

" Spent a large part of three days in inspecting the river banks, gravel strata and river bars. Pottery, several celts, arrow-heads, and paleoliths numerous. Two hearths discovered, the one six and the other nine feet below the surface. A modern brick was found lying just above one of them. Rough implements were gathered from the village sites and in the clay and sand of the river banks. No implement was seen protruding from the gravel layers.
"Rowed up the stream all day Saturday. Three experienced field-searchers were in the boat. No gravel bank was seen which contained implements. We saw no spot in clay bank, on village site or bar where only rude implements of paleolithic type (or approaching that type) were found. The rude objects, tinished objects, pottery, etc., are always found together. Careful searching long continued might reveal isolated paleoliths. The river frequently washes cans, bricks, etc. out of its banks and transports them to remote parts. Just so it might carry a piece of pottery or a paleolith to a gravel bar and deposit it. A finder of an implement thus deposited would attach to it great importance, especially so were he a stranger in the valley."

This important point has been overlooked in the discussion. So far as Ohio goes, I think I am safe in saring, Dr. Metz is the only thorough archæologist who claims to have found paleoliths in the drift. All others have been found by travellers or persons not familiar with the prehistoric sites of occupation. Professor Wright does not claim to have found them himself. How is it that those of us who spend all of our time in archæologic work cannot find them? Were they so numerous in drift, surely we could see them whether we knew anything about geology or not. The type is fixed in everyone's mind, and while a searcher might not be able to name the deposit in which the implement occurred, he certainly could tell the implement when he saw it !

Dr. Cresson - strong in "paleolithic faith" - never found one specimen while he was for four months in my camp in Paint Valley, Ross County. Yet he often searched the creek banks or gravel exposures. My men, all good specimen hunters, quick to see an artificial object, could never find them in any kind of stratified gravel. I lay no claim to a knowledge of the gravels, but had implements been found in them geologists from Columbus or Cincinnati would have examined and named the deposits for me. During the coming summer I will spend as much time as possible in a further search for implements like those found by Metz and Mills. Any number can be found on the surface, but as yet $I$ have not been able to find one in gravel layers. Probably my eyes are not sharp enough !

5,215 Washington Ave., Chicago, Ill., Mar. 24

$$
\text { WARREN K. MOOREHEAD。 }
$$

\section{Probable Causes of Rainy Period in Southern Peru.}

IN ycur issue of Oct. 21, Professor A. E. Douglass of Arequipa Observatory presents important facts evidencing a former rainy period in that region which is now nearly rainless. This change he attributes to a considerable increase in the elevation of the Andes in recent geological times. A most serious objection to this theory is, that in order to entirely cut off the precipitation from the trade-winds, an average height of broad mountain range not exceeding 6.000 to 8,000 feet would be necessary. Our experience in the Hawaiian Islands is that the trade-winds rarely surmount 5,000 feet of mountain, and, if they do this. they still more rarely carry much rain over that height, nearly all the moisture being precipitated upon the windward slope. It seems impossible to suppose that the Peruvian Andes were not more than at least one-half their present height during any recent geological period.

I would suggest that the glacial period was the cause of the former moisture of the climate of Peru. During the reign of ice in the southern hemisphere, it seems probable that the weather of the temperate zone was transferred to the tropic - was pushed towards the equator. Peru would at that time have enjosed the westerly gales now prevalent in southern Chili and Patagonia, together with the heavy rains accompanying those winds.

In support of the very recent existence of such temperate zone climates in the tropics, I will adduce a fact stated to me by Professor A. B. Lyons of Oahu College, who recently found on the now arid slopes of Diamond Head buried land shells, Achatinelloe, of a species now only found upon the cold and wet summit of Kaala, 3,700 feet above the sea. This fact indicates that the present dry and warm climate of southeastern Oahu has been a change from one formerly cold and wet, such as would probably have existed during the ice age. 
In this connection, it will be important to inquire whether any evidences exist of similar changes of climate in southern and Lower California?

Hono ulu, Dec. 7, 1892.

\section{A Peculiar Eye.}

RECENTLY, while dissecting the eye of a domestic animal, the crystalline lens was found to be divided into three lobes by deep clefts on the front (?) side. The lobes are equal and the clefts extend entirely through, so that the posterior surface is cut near the margin, making the lobes triangular in form with rounded outlines, and only slightly connected at the central point and for about one-half the radial distance outward. The eye had been kept several days, had been frozen, and was so opaque from drying and also from distribution of pigment through the aqueous humor that the interior was invisible before dissection, but one who saw the eye when quite fresh stated that it had an unusual appearance. The form appeared so remarkable to the writer that it is mentioner in the hope of drawing from some one better posted in the morphology of the lens some explanation of the peculiar structure.

C. D. McLouth.

Muskegon, Mich.

\section{Speech of Children.}

A PROPOS of Mr. A. Stevenson's interesting article on the speech of children, in science for March 3, and Dr. Howard Lilienthal's communication in the succeeding number, it occurs to me, a bachelor who bas never had much opportunity to become acquainted with young children, since he was a child himself, to inquire whether it would not be a rather difficult matter to teach a very young child the use of the first person, singular. Would he readily distinguish between the proper uses of the various words applied to himself: his name when he was spoken of, "you" when he was spoken to, and "I" or "me" which he should use in speaking of himself? Pronouns are, after all, only words used for convenience instead of nouns, and I cannot see why a person, young or old, cannot think of himself subjectively by his own name as well as by the use of the personal pronoun.

West Roxbury, Mass., Mar. 20, 1893

Francis H. Allen.

\section{Singing of Birds.}

I SHOULD be greatly obliged for any communications respecting the relation of singing in birds to the expression of the emotions. I have, of course, in mind the rival theories of Darwin (origin of song by sexual selection) and Herbert Spencer (song expressire of joyful emotion in general). Does the male sing only, or principally, during the time of courtship? Or is the presence or answering call of the female immaterial?

Good observations can be made incidentally, and with very little trouble, on the commoner species. And the only approach to a settlement of the question seems through statistics. I hope that the readers of Science will assist me in investigating the matter on this basis.

Psychological Laboratory, Ithtca, N. Y.

E. B. TITCHENER

\section{BOOK-REVIEWS.}

Third Annual Report of the Geolngical Survey of Texas, 1891.

E. T. Dumble, State Geologist. Austin, 1892. 461 p. Pl. 16.

THIs volume is quite a bulky one and contains information on a variety of subjects. The State geologist in his annual statement mentions the work that has been carried on during the year covered by the report and gives abstracts of the work of the various assistants. The papers accompanying the report are: Houston County, by W. Kennedy. In this county none of the formations are older than the Eocene. Various sections are given and a considerable portion of the report is devoted to economic geology. Mr. Kennedy also contributes a description of a section from Terrell, Kaufman County, to Sabine Pass, on the Gulf of Mexico. Many details of sections are given, which are of interest mainly to those familiar with the region. Mr. W. T. Cummins has a report upon the geography, topography, and geology of the Llano Estacado, with notes on the country to the westward. This is of considerable interest, as it touches upon a region of which comparatively little is known. The region is likely to be of considerable importance, however, in the development of the State, as recent discoveries have shown the possibility of securing water in sufficient quantity to permit of cultivation over the larger portion of its area. Mr. Cummins, in a foot-note, refers to the various theories advanced to account for the name, discarding them all and retaining at the last the name itself. We prefer to adopt the idea of Professor Hill that the name Llano estacado refers to the palisade character of the escarpment which nearly surrounds the area and makes it one of the most characteristic mesas of the country. The conclusions of Mr. Cummins in regard to the geological structure are that the Quaternary is represented in places on top of the Llano; the Tertiary is exposed at various places in cañons penetrating the edges of the Llano; that the Cretaceous underlies the southern part, forms part of the escarpment on the eastern and southwestern sides, and for a short distance along the northern side in the vicinity of Mt. Tucumcari, New Mexico; and, finally, that the Triassic forms the basal member of the escarpment on all sides. Water can readily be procured in almost all parts of the Llano, although not flowing artesian wells. A good idea may be had of the extent of the area when we observe that no less than 29 counties are included in it. The paper is followed by a discussion of the geology of Tucumcari, New Mexico, in which the author contends from the Cretaceous age of strata previously regarded by Marcou and Hill as Jurassic. It is rather singular that Mr. Cummins concludes that a single specimen of a fossil plant occurring in the beds " is sufficient to establish the fact that the strata are no older than the Cretaceous." This specimen is imperfect, the nervation is " indistinct," but it is concluded to be a dicotyledon, and upon this ground to be of Cretaceous age. The leaf is called Sterculia drakei, a new species, and seemingly a new genus.

Mr. N. F. Drake follows with a paper on the Triassic of Northwestern Texas, and Professor E. D. Cope and Dr. R. W. Shufeldt describe some vertebrates in another paper. Dr. V. Sterki gives a list of shells collected in a dry salt lake near Eddy, New Mexico, and J. A. Taff discusses the Cretaceous area north of the Colorado River. The last paper in the report is on "Trans-Pecos Texas," by von Streeruwitz.

It iz unfortunate that the "Library Catalogue Slips" should not have been made with more regard to accuracy. In the three slips there are no less than thirteen errors.

J. F. J.

The Journal of Geology. Vol. I, No. 1. January-February, 1893. Chicago, The University of Chicago. $112 \mathrm{p}$.

THE first number of a new publication dealing with scientific matters is always eagerly scanned. It was announced some time agn that the Chicago University expected to issue a magazine from its geological department, and the initial number of The Journal of Geology has now come from the press. Its editors are: T. C. Chamberlin, R. D. Salisbury, J. P. Iddings, R. A. F. Penrose, Jr., C. R. Van Hise, C. D. Walcott, and W. H. Holmes. There is besides a corps of associate editors: Sir Archibald Geikie (Great Britain), H. Rosenbusch (Germany), Charles Barrois (France), Albrecht Penck (Austria), Hans Reusch (Norway), Gerard de Geer (Sweden), J. Le Conte (California), G. K. Gilbert (Washington, D.C.), H. S. Williams (Yale University), J. C. Branner (Leland Stanford, Jr., University), G. H. Williams (Johns Hopkins), I. C. Russell (University of Michigan), and Geo. M. Dawson (Canada). These names ought to be a guarantee of an excellent journal. There are, to be sure, several journals already in the field, such as the American Journal of Science, the American Geologist, and the American Naturalist. The first two of these occupy the geological field to a large extent, and the third to a more limited degree. These are more or less dependent upon private enterprise, whereas the new Journal of Geology has the advantage, as an editorial states, "of being published under 